\title{
Phytotoxic activity of extracts obtained from cagaita (Eugenia dysenterica DC. - Myrtaceae) on the growth of black-jack (Bidens pilosa L.)
}

\author{
Marlene Benedita Ribeiro' ${ }^{1}$, Rafael Soares Pozzi Malheiros ${ }^{2 *}$ (D), \\ Luciana Lucas Machado' ${ }^{[}$, Ana Maria Mapeli ${ }^{1}$
}

\author{
1 Universidade Federal do Oeste da Bahia, Centro de Ciências Biológicas e da Saúde, Rua Professor José Seabra de Lemos, \\ 316 - Recanto dos Pássaros. CEP 47808-021, Barreiras, Bahia, Brasil. \\ ${ }^{2}$ Universidade Federal de Viçosa, Departamento de Biologia Vegetal, Avenida Purdue, s/ $\mathrm{n}^{\circ}$ Campus Universitário Edif. CCB II - \\ Centro de Ciências Biológicas II, CEP 36570.900, Viçosa, Minas Gerais, Brasil. \\ * Autor para correspondência: rafaelpozzi@hotmail.com
}

\begin{abstract}
Cagaita (Eugenia dysenterica) is a native plant of the Cerrado with great economic, social and environmental importance. The objective of this work was to determine the phytotoxic potential of extracts of leaf and bark from the stem of E. dysenterica on the initial growth of $B$. pilos $a$ (black-jack). The experiment was performed under laboratory conditions, and the extracts used were: leaf aqueous extract, leaf ethanolic extract, leaf hydroalcoholic extract 70:30, leaf hydroalcoholic extract 50:50, bark from the stem aqueous extract, bark from the stem ethanol extract, bark from the stem hydroalcoholic extract 70:30 and bark from the stem hydroalcoholic extract 50:50. All E. dysenterica leaf and bark from the stem extracts exerted inhibitory effects on the radicle and hypocotyl growth of black-jack seedlings. Thus, E. dysenterica leaf and bark from the stem extracts present high phytotoxic potential and may be useful in studies attempting to find new molecules with bioherbicidal function for controlling spontaneous plants.
\end{abstract}

Keywords: Allelopathy, growth inhibition, spontaneous plant.

RESUMO - Atividade fitotóxica de extratos obtidos de cagaita (Eugenia dysenterica DC.-Myrtaceae) sobre o crescimento de picão preto (Bidens pilosa L.). A cagaita (Eugenia dysenterica) é uma planta nativa do Cerrado com grande importância econômica, social e ambiental. O objetivo deste trabalho foi determinar o potencial fitotóxico de extratos de folhas e cascas do caule de $E$. dysenterica no crescimento inicial de $B$. pilosa (picão-preto). O experimento foi conduzido em condições de laboratório e os extratos utilizados foram: extrato aquoso foliar, extrato etanólico foliar, extrato hidroalcoólico foliar 70:30 extrato hidroalcoólico foliar 50:50, extrato aquoso do caule, extrato etanólico do caule, extrato hidroalcoólico do caule 70:30 e extrato hidroalcoólico do caule 50:50. Todos os extratos de folhas e caules de E. dysenterica exerceram efeitos inibitórios sobre o crescimento da radícula e do hipocótilo de plântulas de picão-preto. Assim, extratos foliares e de caules de E. dysenterica apresentam alto potencial fitotóxico e podem ser úteis em estudos que tentam encontrar novas moléculas com função bioerbicida para o controle de plantas espontâneas.

Palavras-chave: alelopatia, inibição do crescimento, plantas espontâneas

\section{INTRODUCTION}

The control processes for spontaneous plants in agricultural production increase the dependence of synthetic herbicides, causing degradation of ecosystems. In addition, an increase in herbicide-resistant invasive plants has been observed in many farming systems, indicating that new control strategies should emerge through developing natural products which have lower residence time and toxicity to an environment (Souza Filho \& Alves 2002).

Secondary substances produced by plants, including terpenes, phenolic compounds and nitrogen compounds, provide a diversity of chemical structures, offering opportunities for producing new growth inhibitory biomolecules (Taiz et al. 2017). Studies in this area have been carried out based on allelopathy, a science which studies any process involving secondary compounds produced by plants, algae, bacteria and fungi, which positively or negatively influence the growth and development of biological systems (Harun et al. 2014).

These secondary compounds are distributed at varying concentrations in the different plant tissues and throughout their life cycle. These substances cause direct or indirect effects when they are released into the environment through leaching, root exudation, volatilization and/or organic matter decomposition (Borghetti et al. 2013), which may alter cell division and elongation processes, growth-inducing hormonal mechanisms, cell membrane 
permeability, stomatal opening, photosynthesis, respiration, protein synthesis and lipid metabolism upon absorption by the plant (Einhellig 2004).

The Eugenia genus, representative of the Myrtaceae family, covers several species with potential for allelopathic studies, as they present a diversity of chemical compounds with proven allelopathic activity such as phenolics (Reynertson 2008, Jacques 2009, Imatomi et al. 2013, Malheiros et al. 2018). Few studies have been focused on the allelopathic potential of the Myrtaceae family in Brazil (Imatomi et al. 2013), and a lack of research on the allelopathic effect of native species of the Cerrado biome is noteworthy.

It is believed that extracts from Eugenia dysenterica (cagaita) present secondary bioactive metabolites which interfere in the growth of neighboring plants (Malheiros et al. 2018). After an in loco visit, it was verified that the occurrence of these specimens occurred through agglomerates, not coexisting with other plant species in the surroundings, which may be a strong indication of phytotoxic effect. Ethanolic and hydroalcoholic extracts of 70:30 and 50:50 ratios obtained from the leaves of this species inhibited the average growth of Lactuca sativa L. (lettuce) and Zea mays L. (corn) (Malheiros et al. 2016). Pina et al. (2009) reported the negative interference of aqueous extract from $E$. dysenterica leaves on Sesamum indicum L. (sesame) and Raphanus sativus L. (radish). However, there are no reports in the literature demonstrating the phytotoxic effect of cagaita on invasive species such as Bidens Pilosa (Asteraceae - black-jack), considered one of the most infesting plants found in corn and other annual crops, and which usually form dense infestations (Santos \& Cury 2011).

Thus, the objective of this work was to evaluate the phytotoxic effect of aqueous, hydroalcoholic and ethanolic extracts from the leaves and stem bark of E. dysenterica on the germination and seed growth of B. pilosa (Asteraceae - black-jack).

\section{MATERIAL AND METHODS}

Fully expanded leaves and stem bark of ten adult $E$. dysenterica De Candolle plants were collected during the vegetative phase considering diameter at breast height, in December from inside the Serra da Bandeira (-12 $04^{\circ} 48^{\prime \prime}$ $\mathrm{S}$ and $-45^{\circ} 00$ ' $36^{\prime \prime} \mathrm{W}$ ) in the West region of Bahia, Brazil. The area has Cerrado vegetation, exhibiting cerradão and ciliary forest physiognomies.

The plant parts were immediately submitted to extract preparation after collection. The methodologies of Malheiros et al. (2016) were used to prepare the ethanolic, hydroalcoholic and aqueous extracts from leaves and stem bark, respectively. The extracts employed were leaf aqueous extract (LAE), leaf ethanolic extract (LEE), leaf hydroalcoholic extract 70:30 (LHE 70:30), leaf hydroalcoholic extract 50:50 (LHE 50:50), stem aqueous extract (SAE), stem ethanolic extract (SEE), stem hydroalcoholic extract 70:30 (SHE 70:30) and stem hydroalcoholic extract 50:50 (SHE 50:50). Leaf extracts and stem bark were used at concentrations 0, 250,500 and $1000 \mathrm{mg} \mathrm{L}^{-1}$, with the largest obtained by weighing and the others by dilution. The $\mathrm{pH}$ was adjusted to 6.5 after preparing the extract concentrations.

Bidens pilosa (black-jack) seeds were used as target species for preparing the experiments. Filter paper disks contained in previously autoclaved Petri dishes $(9 \mathrm{~cm}$ in diameter) were impregnated with $2 \mathrm{ml}$ (Brasil 2009) of extract concentrations in the bioassays, in addition to the control (distilled water), and then 50 seeds were seeded on each filter paper disc. The experiments were carried out during 2 months in which one type of plant extract was tested each week.

The experiment was maintained in BOD germination chambers with controlled temperature and light $\left(25 \pm 2{ }^{\circ} \mathrm{C}\right.$, $230 \mu \mathrm{m} \mathrm{m}^{-2 \mathrm{~s}-1}$ ) under a light/dark photoperiod of $16 / 8$ hours.

Germination was evaluated daily considering a $2 \mathrm{~mm}$ root protrusion. The analyzed variables were germination percentage (Labouriau 1983) and germination speed index $(\mathrm{GSI})$, according to the formula GSI $=(\mathrm{G} 1 / \mathrm{N} 1)+(\mathrm{G} 2 / \mathrm{N} 2)$ $+(\mathrm{G} 3 / \mathrm{N} 3)+\ldots+(\mathrm{Gn} / \mathrm{Nn})$ (Maguire 1962). The Barnes $\&$ Soeiro (1981) method was employed for the radicle and hypocotyl growth bioassays. The experiment was terminated after three consecutive days of null germination.

The experimental design was completely randomized with five replications, employing 50 seeds as the experimental unit for the germination bioassays and 10 seedlings for growth evaluation. The data were submitted to analysis of variance, and tested for the assumptions of normality, randomness and homogeneity of variances. The treatments were compared by the Tukey test at $5 \%$ probability using the Sisvar ${ }^{\circledR}$ statistical program (Ferreira, 2000).

\section{RESULTS}

Leaf and stem hydroalcoholic extracts promoted inhibition in the germination percentage of B. pilosa at concentrations of 500 and $1000 \mathrm{mg} \mathrm{L}^{-1}$, whereas the aqueous and ethanolic extracts did not cause significant changes in this variable at any concentration used (Tab. 1). The two highest concentrations of the LHE 70:30, LHE 50:50, SHE 70:30 and SHE 50:50 extracts reduced the germination percentage by $36,35,29$ and $34 \%$, respectively, compared to control (Tab. 1).

The GSI was inhibited by 17 and $35 \%$ by LAE at concentrations of 250 and $1000 \mathrm{mg} \mathrm{L}^{-1}$, respectively, while LEE caused a $28 \%$ mean reduction at concentrations of 250 
and $500 \mathrm{mg} \mathrm{L}^{-1}$, and a $58 \%$ reduction at a concentration of $1000 \mathrm{mg} \mathrm{L}^{-1}$ compared to the control. Regardless of the concentration, LHE 70:30, LHE 50:50 and SAE reduced the GSI of $B$. pilosa by 53,51 and $46 \%$, respectively. The SEE promoted an average reduction of $30 \%$ at concentrations of 250 and $500 \mathrm{mg} \mathrm{L}^{-1}$, while the reduction was $56 \%$ at the concentration of $1000 \mathrm{mg} \mathrm{L}^{-1}$ in relation to the control. The SHE 70:30 reduced the GSI by $29 \%$ at the concentration of $250 \mathrm{mg} \mathrm{L}^{-1}$, and by $55 \%$ at the concentrations of 500 and $1000 \mathrm{mg} \mathrm{L}^{-1}$. The SHE 50:50 reduced the seeds GSI by $22 \%$ at the concentration of $250 \mathrm{mg} \mathrm{L}^{-1}$, while the concentrations of 500 and $1000 \mathrm{mg} \mathrm{L}^{-1}$ provided a $46 \%$ reduction (Tab. 2).

All leaf and stem bark extracts had inhibitory effects on the radicle growth of black-jack seedlings. LAE caused an average reduction of $33 \%$ at all concentrations. The LEE caused inhibition of 34,50 and $67 \%$ for the concentrations of 250,500 and $1000 \mathrm{mg} \mathrm{L}^{-1}$, respectively. The LHE 70:30 promoted a reduction of $51 \%$ at the concentration of 250 $\mathrm{mg} \mathrm{L}^{-1}$, while the two higher concentrations reduced the radicle growth by $71 \%$ in relation to the control. In turn, LHE 50:50 $\left(250,500\right.$ and $\left.1000 \mathrm{mg} \mathrm{L}^{-1}\right)$ provided an average inhibition of $61 \%$. The SAE caused an average reduction of $49 \%$ (250 and $\left.500 \mathrm{mg} \mathrm{L}^{-1}\right)$ and $67 \%\left(1000 \mathrm{mg} \mathrm{L}^{-1}\right)$, while SEE inhibited the radicle growth at concentrations of 250 and $500 \mathrm{mg} \mathrm{L}^{-1}$ by $38 \%$, and by $62 \%$ at the concentration of $1000 \mathrm{mg} \mathrm{L}^{-1}$. Lastly, the SHE 70:30 and SHE 50:50 caused an average inhibition of $50 \%$, regardless of concentration (Fig. 1).

In relation to the hypocotyl growth of black-jack seedlings, it was observed that the effect of cagaita extracts was less expressive regarding radicle growth, with the latter being more sensitive to secondary metabolites. The LAE only promoted a decrease at the concentration of $250 \mathrm{mg}$ $\mathrm{L}^{-1}(37 \%)$ in comparison to the control. On the other hand, the LEE only demonstrated an inhibitory effect (52\%) in the two highest concentrations. As for the LHE 70:30, there was an average decrease of $55 \%$ in all concentrations. The LHE 50:50 caused $61 \%$ inhibition at the concentrations of 500 and $1000 \mathrm{mg} \mathrm{L}^{-1}$ in relation to the control. Regarding SAE, no significant differences were observed in hypocotyl growth at any of the tested concentrations. In turn, the SEE only caused a reduction at the highest concentration $(60 \%)$. The SHE 70:30 had a significant effect when used at 500 and $1000 \mathrm{mg} \mathrm{L}^{-1}$, with a mean hypocotyl reduction of $57 \%$. However, the SHE 50:50 (250mg, 500 and $1000 \mathrm{mg}$ $\mathrm{L}^{-1}$ ) promoted an average reduction of $49 \%$ in hypocotyl growth compared to control (Fig. 2).

Table 1. Effect of different leaf and stem bark extracts of Eugenia dysenterica DC. on the germination percentage (G\%) of Bidens pilosa L. seeds.

\begin{tabular}{lcccccccc}
\hline $\begin{array}{l}\text { Concentration } \\
\left(\mathbf{m g L}^{-1}\right)\end{array}$ & LAE & LEE & LHE 70:30 & LHE 50:50 & SAE & SEE & SHE 70:30 & SHE 50:50 \\
\hline 0 & $64.00 \mathrm{~A}$ & $64.00 \mathrm{~A}$ & $64.00 \mathrm{~A}$ & $64.00 \mathrm{~A}$ & $64.00 \mathrm{~A}$ & $64.00 \mathrm{~A}$ & $64.00 \mathrm{~A}$ & $64.00 \mathrm{~A}$ \\
250 & $59.84 \mathrm{~A}$ & $59.14 \mathrm{~A}$ & $60.33 \mathrm{~A}$ & $59.35 \mathrm{~A}$ & $59.18 \mathrm{~A}$ & $58.81 \mathrm{~A}$ & $58.16 \mathrm{~A}$ & $59.11 \mathrm{~A}$ \\
500 & $57.48 \mathrm{~A}$ & $59.76 \mathrm{~A}$ & $41.56 \mathrm{~B}$ & $42.00 \mathrm{~B}$ & $57.00 \mathrm{~A}$ & $57.25 \mathrm{~A}$ & $48.16 \mathrm{~B}$ & $42.48 \mathrm{~B}$ \\
1000 & $58.75 \mathrm{~A}$ & $57.70 \mathrm{~A}$ & $40.18 \mathrm{~B}$ & $41.14 \mathrm{~B}$ & $59.40 \mathrm{~A}$ & $58.14 \mathrm{~A}$ & $42.12 \mathrm{~B}$ & $41.18 \mathrm{~B}$ \\
\hline
\end{tabular}

Means followed by the same letter in the column do not differ from each other by the Tukey test at $5 \%$ probability. Leaf Aqueous Extract (LAE), Leaf Ethanolic Extract (LEE), Leaf Hydroalcoholic Extract 70:30 (LHE 70:30), Leaf Hydroalcoholic Extract 50:50 (LHE 50:50), Stem aqueous extract (SAE), Stem ethanolic extract (SEE), Stem hydroalcoholic extract 70:30 (SHE 70:30), and Stem hydroalcoholic extract 50:50 (SHE 50:50).

Table 2. Effect of different leaf and stem bark extracts of Eugenia dysenterica DC. on the germination speed index (GSI) of Bidens pilosa L. seeds.

\begin{tabular}{lcccccccc}
\hline $\begin{array}{l}\text { Concentration } \\
\left(\mathbf{m g L}^{-1}\right)\end{array}$ & LAE & LEE & LHE 70:30 & LHE 50:50 & SAE & SEE & SHE 70:30 & SHE 50:50 \\
\hline 0 & $18.20 \mathrm{~A}$ & $18.20 \mathrm{~A}$ & $18.20 \mathrm{~A}$ & $18.20 \mathrm{~A}$ & $18.20 \mathrm{~A}$ & $18.20 \mathrm{~A}$ & $18.20 \mathrm{~A}$ & $18.20 \mathrm{~A}$ \\
250 & $15.10 \mathrm{~B}$ & $13.60 \mathrm{~B}$ & $9.95 \mathrm{~B}$ & $7.30 \mathrm{~B}$ & $10.60 \mathrm{~B}$ & $13.30 \mathrm{~B}$ & $12.90 \mathrm{~B}$ & $14.20 \mathrm{~B}$ \\
500 & $19.61 \mathrm{~A}$ & $12.20 \mathrm{~B}$ & $8.18 \mathrm{~B}$ & $9.60 \mathrm{~B}$ & $9.65 \mathrm{~B}$ & $12.20 \mathrm{~B}$ & $8.41 \mathrm{C}$ & $9.79 \mathrm{C}$ \\
1000 & $11.75 \mathrm{C}$ & $7.70 \mathrm{C}$ & $7.61 \mathrm{~B}$ & $9.94 \mathrm{~B}$ & $9.40 \mathrm{~B}$ & $8.04 \mathrm{C}$ & $8.10 \mathrm{C}$ & $9.68 \mathrm{C}$ \\
\hline
\end{tabular}

Means followed by the same letter in the column do not differ from each other by the Tukey test at $5 \%$ probability. Leaf Aqueous Extract (LAE), Leaf Ethanolic Extract (LEE), Leaf Hydroalcoholic Extract 70:30 (LHE 70:30), Leaf Hydroalcoholic Extract 50:50 (LHE 50:50), Stem aqueous extract (SAE), Stem ethanolic extract (SEE), Stem hydroalcoholic extract 70:30 (SHE 70:30), and Stem hydroalcoholic extract 50:50 (SHE 50:50). 


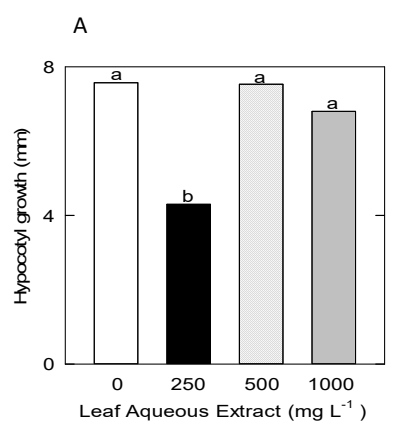

E

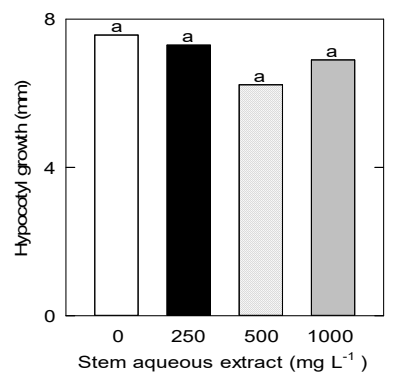

B

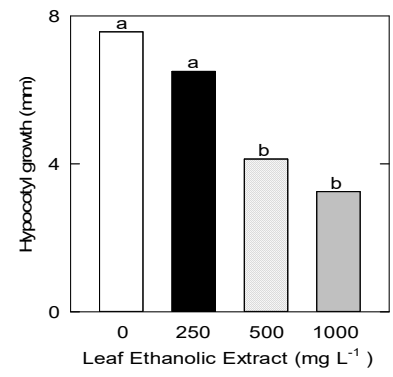

$\mathrm{F}$

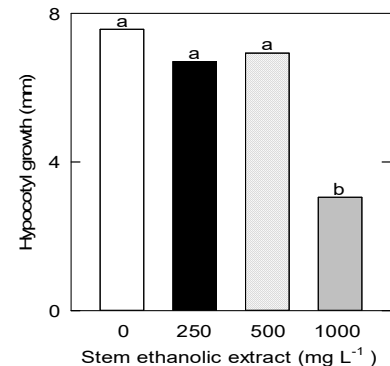

c
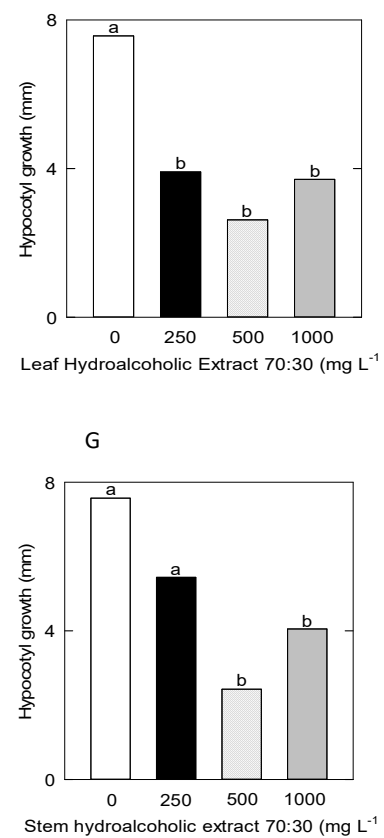

D

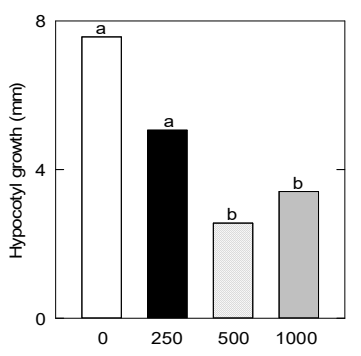

$\mathrm{H}$

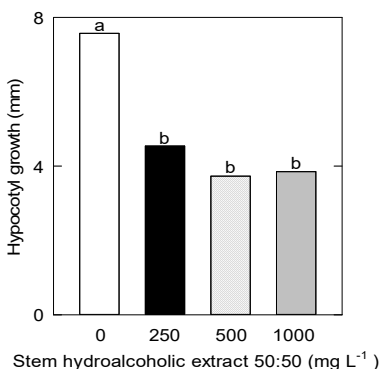

Figs. 1 A-H. Effect of different leaf and stem extracts of Eugenia dysenterica DC. on the radicle growth (mm) of Bidens pilosa L. seeds. Means followed by the same letter in the column do not differ from each other by the Tukey test at 5\% probability. A. Leaf Aqueous Extract (LAE); B. Leaf Ethanolic Extract (LEE); C. Leaf Hydroalcoholic Extract 70:30 (LHE 70:30); D. Leaf Hydroalcoholic Extract 50:50 (LHE 50:50), E. Stem aqueous extract (SAE); F. Stem ethanolic extract (SEE), G. Stem hydroalcoholic extract 70:30 (SHE 70:30); H. Stem hydroalcoholic extract 50:50 (SHE 50:50).
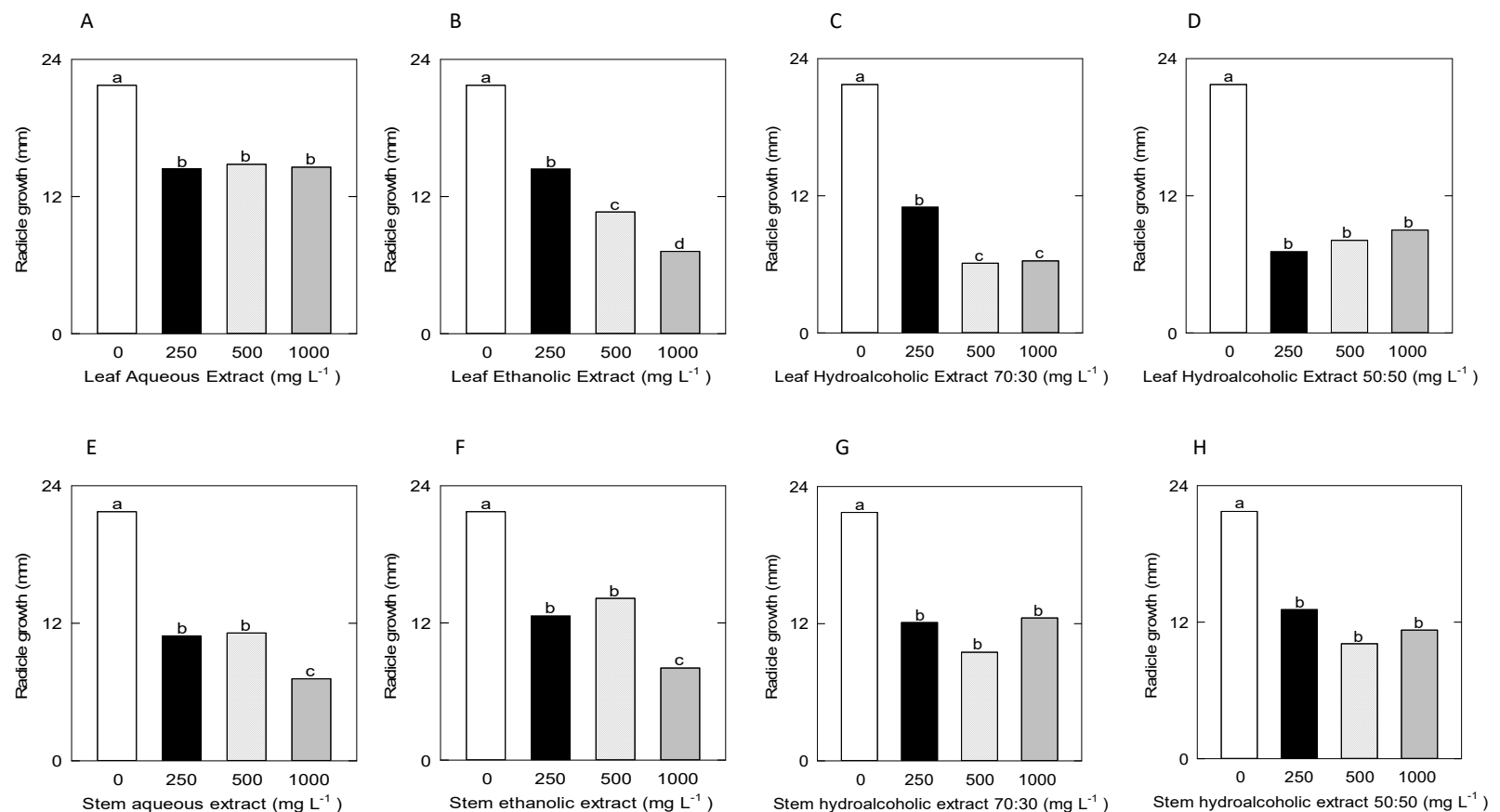

Figs. 2 A-H. Effect of different leaf and stem extracts of Eugenia dysenterica DC. on the hypocotyl growth (mm) of Bidens pilosa L. seeds. Means followed by the same letter in the column do not differ from each other by the Tukey test at 5\% probability. A. Leaf Aqueous Extract (LAE); B. Leaf Ethanolic Extract (LEE); C. Leaf Hydroalcoholic Extract 70:30 (LHE 70:30); D. Leaf Hydroalcoholic Extract 50:50 (LHE 50:50); E. Stem aqueous extract (SAE); F. Stem ethanolic extract (SEE); G. Stem hydroalcoholic extract 70:30 (SHE 70:30); H. Stem hydroalcoholic extract 50:50 (SHE 50:50). 


\section{DISCUSSION}

The target species in the present study demonstrated a delay in germination and germination speed index (Tables 1 and 2). The effect promoted by ethanolic and aqueous extracts obtained from $E$. dysenterica leaves may be associated with the presence of several secondary compounds, including phenols, hydrolysable tannins, flavonols, flavanones, flavanones, xanthones, flavones, free steroids and saponins (Malheiros et al. 2019). The most expressive results were promoted by hydroalcoholic extracts, agreeing with the study by Lousada et al. (2012) which showed that the black-jack germination was also inhibited by lemongrass hydroalcoholic extracts. Allelopathic compounds alter seed germination through a multiplicity of effects on physiological and biochemical processes, since there are hundreds of different structures upon which they exhibit multiple phytotoxic effects (Imatomi et al. 2013), as is the case with phenolic compounds which affect cell wall elasticity and block mitochondrial respiration (Weir et al. 2004), and saponins which showed action on the cell membrane, modifying cell permeability (Alves \& Santos, 2002).

Considering weeds, the delay in seed germination may be favorable because the longer the seeds remain in the field without germination, the longer they will be exposed to pathogens, environmental factors and insect predation (Aires et al. 2005). In addition, some authors report that plant extracts may present greater inhibitory potential in seed germination than the synthetic herbicide itself, with the advantage of being biodegradable, thereby reducing soil and aquifer contamination (Silva et al. 2011).

Black-jack radicle growth was inhibited by all tested extracts, and the most pronounced effects were generally observed at higher concentrations (Fig. 1). This is favorable because it makes it difficult to establish the plant, since the root is essential for support and absorption of water and nutrients. The inhibitory effect observed for radicle growth was similar to that observed for hypocotyl growth (Fig. 2). This is possible since the same damaged radicles can continue to absorb solutes, which eventually affects the shoot (Burgos et al. 2004). In addition, allelopathic effects are mainly observed in seedling development as a whole, and plant length is the parameter most commonly used to evaluate allelopathic action (Souza Filho \& Alves 2002).

Leaf and stem hydroalcoholic extracts were the treatments which had greater inhibitory potential on the black-jack growth (Figs. 1 and 2). The plants produce numerous chemically diverse compounds with wide variation in polarity and distribution in the plant, with it being recognized that polar extracts can provide high expression of bioactive compounds, especially those related to phenolic compounds (Chon 2002, Leu 2002). The most expressive extracts on B. pilosa in this work have intermediate polarity (hydroalcoholic extract), indicating that extraction of the secondary compounds present in cagaita can be related to the balance between the polarities. In addition, the leaf hydroalcoholic extracts (LHE 70:30 and LHE 50:50) showed the highest inhibition percentage for radicle and hypocotyl growth, respectively. This fact suggests that these extracts could have greater extraction capacity for inhibitory compounds on growth. A recent study has shown that the phytotoxic potential of E. dysenterica in model species is possibly associated with the presence of phenolic compounds, tannins, flavonoids and saponins present in its leaves (Malheiros et al. 2018). Thus, E. dysenterica leaf and stem extracts present high phytotoxic potential and may be useful in studies attempting to find new molecules with bioherbicidal function to control spontaneous plants. However, field tests and a phytochemical analysis of the extracts are necessary to provide effective proof of the phytotoxic effects observed in this work.

\section{REFERENCES}

Aires, S.S.; Ferreira, A.G. \& Borghetti, F. 2005. Efeito alelopático de folhas e frutos de Solanum lycocarpum A. St.-Hil. (Solanaceae) na germinação e crescimento de Sesamun indicum L. (Pedaliaceae) em solo sob três temperaturas. Acta Botanica Brasilica 19:339-344.

Alves, S. M. \& Santos, L. S. 2002. Natureza química dos agentes alelopáticos. In Alelopatia princípios básicos e aspectos gerais (A.P.S. Souza Filho \& S.M. Alves, eds.). Embrapa Amazônia Oriental, Belém, p.25-47.

Barnes, R.A. \& Soeiro, O.M. 1981.The alkaloids of Croton salutaris. Phytochemistry 20:543-544.

Borghetti, F.; Lima, E.C. \& Silva, L.C.R. 2013. A simple procedure for the purification of active fractions in aqueous extracts of plants with allelopathic properties. Acta Botanica Brasilica 27:50-53.

Brasil. 2009. Regras para análise de sementes. $1^{\circ}$ edição. Mapa/ACS. Brasília, $370 \mathrm{p}$.

Burgos, N.R.; Talbert, R.E.; Kim, K.S. \& Kuk, Y.I. 2004.Growth inhibition and root ultra structure of cucumber seedlings exposed to allelochemicals from rye. Journal of Chemical Ecology 30:671-690.

Chon, S.U. 2002.Effects of alfafa extracts and phenolic allelochemicals on early seedling growth and root morphology of alfafa and barnyard grass. Crop Protection 21:1077-1082.

Einhellig, F.A. 2004. Mode of allelochemical action of phenolic compounds. In Allelopathy: chemistry and mode of action of allelochemicals (F.A. Macías, J.C.G. Galindo, J.M.G. Molinillo \& H.G. Cutler, eds.). CRC Press, Boca Raton, p. 217-238.

Ferreira, D.F. 2000. Análises estatísticas por meio do Sisvar para Windows versão 4.0. In Reunião Anual da Região Brasileira da Sociedade Internacional de Biometria, 45, Anais... SP: SIB, São Carlos, p. 255-258.

Harun, M.A.Y.A.; Johnson, R.W.R. \& Uddin, M.Z. 2014. Allelopathic potential of Chrysanthemoides monilifera subsp. monilifera (boneseed): a novel weapon in the invasion processes. South African Journal of Botany 93:157-166.

Imatomi, M.; Novaes, P. \& Gualtieri, S.C.J. 2013. Interspecific variation in the allelopathic potential of the family Myrtaceae. Acta Botanica Brasilica 27:54-61.

Jacques, A.C.; Pertuzatti, P.B.; Barcia, M.T. \& Zambiazi, R.C. 2009. Nota científica: Compostos bioativos em pequenas frutas cultivadas na 
região sul do Estado do Rio Grande do Sul. Brazilian Journal Food Technology 12:123-127.

Labouriau, L.G. 1983. A germinação das sementes. $1^{\circ}$ edição. Secretaria Geral da O.E.A. Washington, $467 \mathrm{p}$.

Leu, E. 2002. Polyphenolic allelochemicals from the aquatic angiosperm Myriophyllum spicatum in inhibit photosystem II. Plant Physiology 130:2111-2118.

Lousada, L.L.; Lemos, G.C.S.; Freitas, S.P.; Daher, R.F. \& Esteves, B.S. 2012. Bioatividade de extratos hidroalcoólicos de Cymbopogon citratus (DC.) Stapf. sobre picão preto-preto (Bidens pilosa L.) e alface (Lactuca sativa L.). Revista Brasileira Plantas Medicinais 14:282-286.

Maguire, J.D. 1962. Speed of germination-aid in selection and evaluation for seedling emergence and vigor. Crop Science 2:176-177.

Malheiros, R.P.; Mapeli, A.M. \& Machado, L.L. 2018.Phytochemical and phytotoxic investigation of the aqueous leaf extract of Eugenia dysenterica DC. under laboratory conditions. Ciência e Natura 40:e55.

Malheiros, R.P.; Mapeli, A.M. \& Machado, L.L. 2016. Atividades antioxidante e alelopática de extratos foliares obtidos de Eugenia dysenterica. Ciência e Natura 38:601-609.

Malheiros, R.P.; Santos, F.S.; Machado, L.L. \& Mapeli, A.M. 2019. Phytochemical characterization and effect of cagaita leaf extracts on Aspergillus sp. Floresta e Ambiente 26: e20170029.
Pina, G.O.; Borghetti, F.; Silveira, C.E.S. \& Pereira, L.A.R. 2009. Effects of Eugenia dysenterica extracts on the growth of sesame and radish. Allelopathy Journal 23:313-322.

Reynertson, K.A.; Wallace, A.M.; Adachi, S.; Gil, R.R.; Yang, H.; Basile, M.J. \& D'Armiento, J. 2008. Quantitative analysis of antiradical phenolic constituents from fourteen edible Myrtaceae fruits. Food Chemistry 109:883-890.

Santos, J.B.\& Cury, J.P. 2011. Picão-preto: uma planta daninha especial em solos tropicais. Planta Daninha 29:1159-1171.

Silva, V.S.; Cândido, A.C.S.; Muller, C.; Laura, V.A.; Faccenda, O.; Simionatto, E.; Hess, S.C. \& Peres, M.T.L.P. 2011. Potencial fitotóxico de Dicranopteris flexuosa (Schrad.) Underw. (Gleicheniaceae). Acta Botânica Brasilica 25:95-104.

Souza Filho, A.P.S. \& Alves, S.M. 2002. Alelopatia, Princípios Básicos e Aspectos Gerais. $1^{a}$. Edição. Embrapa Amazônia Oriental. Belém, $244 \mathrm{p}$.

Taiz, L., Zeiger, E., Moller, I.M. \& Murphy, A. 2017. Fisiologia e Desenvolvimento Vegetal. $6^{\text {a }}$ edição. Artmed. Porto Alegre, 888 p.

Weir, T.L.; Park, S.W. \& Vivanco, J.M. 2004. Biochemical and physiological mechanisms mediated by allelochemicals. Current Opinion in Plant Biology 7:472-479. 